

Cite this: J. Anal. At. Spectrom., 2016, 31, 197

Received 20th July 2015

Accepted 7th September 2015

DOI: 10.1039/c5ja00293a

www.rsc.org/jaas

\title{
Elemental bio-imaging using laser ablation-triple quadrupole-ICP-MS
}

\author{
David P. Bishop, $\uparrow^{\dagger}$ David Clases,,$\dagger^{\mathrm{b}}$ Fred Fryer, ${ }^{c}$ Elizabeth Williams, ${ }^{e}$ Simon Wilkins, ${ }^{\dagger}$ \\ Dominic J. Hare, ${ }^{\text {ad }}$ Nerida Cole, ${ }^{a}$ Uwe Karst $^{\mathrm{b}}$ and Philip A. Doble ${ }^{\star a}$
}

\begin{abstract}
Elemental bio-imaging (EBI) of trace metal distributions in tissue sections is typically performed by laser ablation-single quadrupole-inductively coupled plasma-mass spectrometry (LA-ICP-SQ-MS) in which the sensitivity of biologically relevant elements such as Fe may be inhibited by polyatomic interferences. The triple quadrupole ICP-MS (ICP-QQQ-MS) is designed to reduce interferences and was examined for its potential application to EBI. Three tune modes; a no-gas, an $\mathrm{H}_{2}$, and an $\mathrm{O}_{2} / \mathrm{H}_{2}$ tune were developed and investigated for their suitability. All three performed well with high signal to noise ratios and low limits of detection. The $\mathrm{O}_{2} / \mathrm{H}_{2}$ tune was applied to a prostate cancer biopsy sample, with high levels of $\mathrm{Zn}$ found in the area correlating with the cancer. The oxygen mass shift was applied to image P and Se in a mouse brain. The unique focussing properties of the ICP-QQQ-MS and the ability to use mixed cell gases provided sensitive analyses of all measured isotopes with the $\mathrm{O}_{2} / \mathrm{H}_{2}$ tune, including those unaffected by mass shift reactions.
\end{abstract}

\section{Introduction}

A wide range of biological processes rely on the presence of metals which are integral to protein stability and function. It is estimated that approximately half of all enzymes require metal cofactors for activity, ${ }^{\mathbf{1}}$ and the measurement of the spatial distribution of trace elements is vital for understanding basic biological processes. ${ }^{2-4}$ Elemental bio-imaging (EBI) by laser ablation-inductively coupled plasma-mass spectrometry (LAICP-MS) has been used to determine metal distribution in various samples including nematodes, ${ }^{5}$ murine brains ${ }^{6,7}$ and human tissue, ${ }^{\mathbf{8}, 9}$ and has the potential for incorporation into clinical practice for diagnosis and prognosis. ${ }^{\mathbf{1 0 - 1 2}}$ The low cost single quadrupole (SQ) ICP-MS is the most widely available commercial instrument, which in 2008 accounted for over $95 \%$ of all installed ICP-MS systems, ${ }^{13}$ and is the most common mass analyser in the LA-ICP-MS imaging field. ${ }^{14}$

${ }^{a}$ Elemental Bio-imaging Facility, University of Technology Sydney, Broadway, New South Wales, 2007, Australia. E-mail: philip.doble@uts.edu.au; Fax: +61 29514 1460; Tel: +61295141792

${ }^{b}$ Institute of Inorganic and Analytical Chemistry, University of Münster, Münster, Germany

${ }^{c}$ Agilent Technologies, Mulgrave, Victoria, Australia

${ }^{d}$ The Florey Institute of Neuroscience and Mental Health, The University of Melbourne, Parkville, Victoria, Australia

${ }^{e}$ Australian Prostate Cancer Research Centre - Queensland, Institute of Health and Biomedical Innovation, School of Biomedical Sciences, Queensland University of Technology, Translational Research Institute, Brisbane, Queensland, Australia

${ }^{f}$ Department of Surgery, Cabrini Monash University, Malvern, Melbourne, Australia $\dagger$ These authors contributed equally.
The dry plasma conditions of LA-ICP-MS have less matrixbased polyatomic species when compared against wet plasmas, ${ }^{\mathbf{1 5}}$ however spectral interferences are still present for many biologically relevant trace elements (Table 1). Typical approaches for polyatomic interference mitigation with a collision/reaction cell either by kinetic energy discrimination or chemically induced dissociation ${ }^{\mathbf{1 6}}$ in wet plasmas may also be applied to elemental bio-imaging, e.g. introduction of $\mathrm{H}_{2}$ gas into the reaction cell to remove the interference on ${ }^{56} \mathrm{Fe}$ by ${ }^{40} \mathrm{Ar}^{16} \mathrm{O}^{+} .{ }^{17}$ Alternatively, higher mass resolution sector-field instruments (ICP-SF-MS) are occasionally employed to resolve analytes from confounding polyatomics. ${ }^{18}$ However, ICP-SF-MS are costly, and compromises between resolution and ion transmission are required.

The recently-introduced triple quadrupole ICP-MS (ICPQQQ-MS) is designed to mitigate interferences in a number of ways. ${ }^{19}$ The geometry consists of three mass filters. In MS/MS mode the first quadrupole (Q1) filters the mass-to-charge ratio $(\mathrm{m} / \mathrm{z})$ of interest prior to introduction into an ion-guide (Q2), which can be filled with a collision and/or reaction gas. The final quadrupole (Q3) again filters the desired analyte, either on its original mass or the mass shift of a known reaction product. ${ }^{20}$ In bandpass mode, ion transmission through Q1 may be manipulated by varying the scan line slope (SLS) and scan line gain (SLG) factors. ${ }^{20}$

The ICP-QQQ-MS has been applied to analytes that are difficult to detect at low concentrations by ICP-SQ-MS, including phosphorus (P), sulfur (S) and silicon (Si) in organic matrices. ${ }^{21}$ Oxygen $\left(\mathrm{O}_{2}\right)$ may be reacted with these kineticallyfavoured analytes to form an $\mathrm{MO}^{+}$mass that is filtered by Q3, 
Table 1 Target elements and potential interferences ${ }^{30}$

\begin{tabular}{|c|c|c|}
\hline Isotope & $\begin{array}{l}\text { Natural } \\
\text { abundance (\%) }\end{array}$ & Potential interferences \\
\hline${ }^{31} \mathrm{P}$ & 100 & $\begin{array}{l}{ }^{14} \mathrm{~N}^{16} \mathrm{O}^{1} \mathrm{H}^{+},{ }^{15} \mathrm{~N}^{15} \mathrm{~N}^{1} \mathrm{H}^{+}, \\
{ }^{15} \mathrm{~N}^{16} \mathrm{O}^{+},{ }^{14} \mathrm{~N}^{17} \mathrm{O}^{+},{ }^{13} \mathrm{C}^{18} \mathrm{O}^{+},{ }^{12} \mathrm{C}^{18} \mathrm{O}^{1} \mathrm{H}^{+}\end{array}$ \\
\hline${ }^{55} \mathrm{Mn}$ & 100 & $\begin{array}{l}{ }^{40} \mathrm{Ar}^{14} \mathrm{~N}^{1} \mathrm{H}^{+},{ }^{39} \mathrm{~K}^{16} \mathrm{O}^{+},{ }^{40} \mathrm{Ar}^{15} \mathrm{~N}^{+},{ }^{38} \mathrm{Ar}^{17} \mathrm{O}^{+}, \\
{ }^{36} \mathrm{Ar}^{18} \mathrm{O}^{1} \mathrm{H}^{+},{ }^{38} \mathrm{Ar}^{16} \mathrm{O}^{1} \mathrm{H}^{+}\end{array}$ \\
\hline${ }^{56} \mathrm{Fe}$ & 91.66 & $\begin{array}{l}{ }^{40} \mathrm{Ar}^{16} \mathrm{O}^{+},{ }^{40} \mathrm{Ca}^{16} \mathrm{O}^{+},{ }^{40} \mathrm{Ar}^{15} \mathrm{~N}^{1} \mathrm{H}^{+} \\
{ }^{38} \mathrm{Ar}^{18} \mathrm{O}^{+},{ }^{38} \mathrm{Ar}^{17} \mathrm{O}^{1} \mathrm{H}^{+}\end{array}$ \\
\hline${ }^{63} \mathrm{Cu}$ & 69.1 & $\begin{array}{l}{ }^{31} \mathrm{P}^{16} \mathrm{O}_{2}{ }^{+},{ }^{40} \mathrm{Ar}^{23} \mathrm{Na}^{+},{ }^{47} \mathrm{Ti}^{16} \mathrm{O}^{+},{ }^{23} \mathrm{Na}^{40} \mathrm{Ca}^{+}, \\
{ }^{46} \mathrm{Ca}^{16} \mathrm{O}_{1} \mathrm{H}^{+},{ }^{36} \mathrm{Ar}^{12} \mathrm{C}^{14} \mathrm{~N}^{1} \mathrm{H}^{+},{ }^{14} \mathrm{~N}^{12} \mathrm{C}^{37} \mathrm{Cl}^{+}, \\
{ }^{16} \mathrm{O}^{12} \mathrm{C}^{35} \mathrm{Cl}^{+}\end{array}$ \\
\hline${ }^{66} \mathrm{Zn}$ & 27.81 & $\begin{array}{l}{ }^{50} \mathrm{Ti}^{16} \mathrm{O}^{+},{ }^{34} \mathrm{~S}^{16} \mathrm{O}_{2}+,{ }^{33} \mathrm{~S}^{16} \mathrm{O}_{2}{ }^{1} \mathrm{H}^{+}, \\
{ }^{32} \mathrm{~S}^{16} \mathrm{O}^{18} \mathrm{O}^{+},{ }^{32} \mathrm{~S}^{17} \mathrm{O}_{2}^{+},{ }^{33} \mathrm{~S}^{16} \mathrm{O}^{17} \mathrm{O}^{+} \\
{ }^{32} \mathrm{~S}^{34} \mathrm{~S}^{+},{ }^{33} \mathrm{~S}_{2}^{+}\end{array}$ \\
\hline${ }^{78} \mathrm{Se}$ & 23.52 & ${ }^{40} \mathrm{Ar}^{38} \mathrm{Ar}^{+},{ }^{38} \mathrm{Ar}^{40} \mathrm{Ca}^{+}$ \\
\hline${ }^{80} \mathrm{Se}$ & 49.82 & ${ }^{40} \mathrm{Ar}_{2}{ }^{+},{ }^{32} \mathrm{~S}^{16} \mathrm{O}_{3}{ }^{+}$ \\
\hline
\end{tabular}

removing all other interfering species. This approach had superior detection limits when compared against isotope dilution (ID) - ICP-SF-MS. ${ }^{21}$ The $\mathrm{O}^{+}$mass shift method has also been used to determine metals and heteroatoms in a range of biological, environmental and organic matrices. ${ }^{22-26}$ Further, the ability of some elements to form an asymmetric charge transfer species in the presence of $\mathrm{O}_{2}$, leading to the detection of ${ }^{16} \mathrm{O}_{2}{ }^{+}$ adducts has been exploited to overcome particularly difficult isobaric interferences; ${ }^{27}$ while others have relied on the formation of adducts such as $\mathrm{Ti}\left(\mathrm{NH}_{3}\right)_{6}{ }^{+}$or used $\mathrm{N}_{2} \mathrm{O}$ in the reaction for this purpose. ${ }^{28,29}$

Here, we describe the first use of an ICP-QQQ-MS in elemental bio-imaging to improve the detection of elements that are subject to potential interferences in biological tissues via mass-shift whilst maintaining the detection sensitivity of onmass analytes. We have evaluated three tune conditions with matrix matched standards to determine effects on the limits of analysis. The mass shift tune was then applied to examine biologically significant elements in histological sections of mouse brain and prostate cancer biopsy material.

\section{Experimental}

\section{Instrumentation}

All analyses were performed on an Agilent 8800 Series ICP-QQQMS (Agilent Technologies, Mulgrave, Victoria, Australia), coupled to a New Wave Research NWR193 laser ablation unit (Kennelec Scientific, Mitcham, Victoria, Australia), equipped with an ArF laser emitting nanosecond laser pulses at $193 \mathrm{~nm}$. Samples and standards were ablated with a $50 \mu \mathrm{m}$ spot size scanning at $200 \mu \mathrm{m} \mathrm{s}^{-1}$. S-lenses with Pt sampler and skimmer cones were used in the ICP-QQQ-MS. The performance of the ICP-QQQ-MS was monitored daily with a solution based tuning procedure (MicroMist concentric nebuliser and Scott-type double-pass spray chamber; Glass Expansion, West Melbourne, Victoria, Australia). To maximise sensitivity and ensure a low oxide formation ( $\mathrm{ThO} / \mathrm{Th}<0.3 \%$ ) with LA-conditions, a NIST 612 Trace Element in Glass CRM was ablated with a $\mathrm{H}_{2}$ tune $\left(\mathrm{H}_{2}\right.$ as reaction gas with $3 \mathrm{~mL} \mathrm{~min}^{-1}$ ) in bandpass mode (SLS/SLG: 0.70/0.90). High purity liquid Ar boil-off was used (Ace Cryogenics, Castle Hill, New South Wales, Australia) as the carrier gas. Ultrahigh purity $\mathrm{H}_{2}(99.999 \%)$ and/or ultrahigh purity $\mathrm{O}_{2}$ (99.995\%) were used as the reaction/collision gas (BOC, North Ryde, New South Wales, Australia).

\section{Tune development}

Three tune conditions - no gas, hydrogen and hydrogen/oxygen were initially optimised for solution introduction with $\mathrm{x}$-lenses in the ICP-QQQ-MS interface with a $1 \mu \mathrm{g} \mathrm{\textrm {L } ^ { - 1 }}$ solution of $\mathrm{Li}, \mathrm{Co}$, $\mathrm{Y}, \mathrm{Ce}$ and $\mathrm{Tl}$ prior to adaptation for LA conditions. The lens parameters with the largest influence on signal or background were octopole bias, deflector potential and energy discrimination.

In order to use these tunes for laser ablation, S-lenses were used to increase the ion throughput and the sensitivity. Integration times were adapted to the spot size and scan speed as determined by Lear et al. ${ }^{17}$ The change from wet-plasma conditions to dry-plasma conditions required further fine tuning adjustments, which were performed with the ablation of the NIST 612 Trace Element in Glass reference standard. The final tune parameters are shown in Table 2 and were used for all further experiments described.

The no-gas and $\mathrm{H}_{2}$ tunes were optimised using bandpass mode. The $\mathrm{H}_{2}$ cell gas flow rate was $3 \mathrm{~mL} \mathrm{~min}^{-1}$. An SLS-factor variation was performed to maximise sensitivity and minimise background equivalent concentration (BEC). The BEC was calculated according to eqn (1).

$$
\mathrm{BEC}=\frac{Y}{S}
$$

where $Y$ is the $y$-intercept of the regression line and $S$ is the sensitivity, obtained from the slope of the regression line. The mixed $\mathrm{H}_{2} / \mathrm{O}_{2}$ tune was evaluated for MS/MS mass shift and on mass detection. Se and $\mathrm{P}$ were monitored as their mass-shift species ${ }^{78 / 80} \mathrm{Se}^{16} \mathrm{O}^{+}$and ${ }^{31} \mathrm{P}^{16} \mathrm{O}^{+}(\mathrm{m} / z$ 94, 96 and 47$)$. The remaining elements were monitored on-mass.

The relative performance of each of these tune conditions was investigated by construction of calibration curves following laser ablation of matrix matched standards.

\section{Calibration and specifications}

Calibration curves and construction of images were performed in ISIDAS, an in-house developed imaging software, with MayaVi 2 and Paraview used for image visualisation. ${ }^{31}$ The resulting calibration equations were used to convert the signal intensities of every voxel in each image to concentrations ( $\mu \mathrm{g}$ $\mathrm{g}^{-1}$ ). The limit of detection (LOD) and limit of quantification (LOQ) were determined from calibration curves using $3 \sigma$ and $10 \sigma$ calculations, respectively.

\section{Preparation of tissue standards}

Tissue standards were prepared as previously described. ${ }^{32}$ Briefly, sheep brains were homogenised on ice using a tissue homogeniser (Omni Scientific; Kennesaw GA, USA), fitted with 
Table 2 Optimal tune parameters for each tune

\begin{tabular}{lll}
\hline & $\mathrm{O}_{2}$ & $\mathrm{H}_{2}$ and no gas \\
\hline Deflector potential & $-11 \mathrm{~V}$ & $3 \mathrm{~V}$ \\
Energy discrimination & $-6.1 \mathrm{~V}$ & $4 \mathrm{~V}$ \\
potential & & \\
Octopole bias & $-16.9 \mathrm{~V}$ & -20 \\
$\mathrm{O}_{2}$ gas flow & $0.56 \mathrm{~mL} \mathrm{~min}^{-1}$ & $0 \mathrm{~mL} \mathrm{~min}^{-1}$ \\
$\mathrm{H}_{2}$-gas flow & $1.1 \mathrm{~mL} \mathrm{~min}^{-1}$ & $3 \mathrm{~mL} \mathrm{~min}^{-1}$ or $0 \mathrm{~mL} \mathrm{~min}^{-1}$
\end{tabular}

disposable $7 \mathrm{~mm} \times 110 \mathrm{~mm}$ polycarbonate hard tissue OmniTips $^{\mathrm{TM}}$. The tissue was then spiked with standard metal solutions prepared in $1 \%(\mathrm{v} / \mathrm{v}) \mathrm{HNO}_{3}$ from chloride, sulfate or nitrate salts of $\mathrm{Mn}, \mathrm{Fe}, \mathrm{Cu}, \mathrm{Zn}$, Se; minimum purity: $99.995 \%$ (Sigma-Aldrich, Castle Hill, NSW, Australia). The salts were distributed through the tissue by a second homogenisation step. Six ca. $50 \mathrm{mg}$ aliquots of each standard were digested in 4 $\mathrm{mL} 69 \% \mathrm{HNO}_{3}$ and $1 \mathrm{~mL} 30 \% \mathrm{H}_{2} \mathrm{O}_{2}$ in a Milestone MLS 1200 microwave digester (Milestone, Sorisole, Italy), diluted to approximately $50 \mathrm{~g}$ (accurately measured on an analytical balance), and analysed with an Agilent 7500cx ICP-MS (Agilent Technologies Australia, Mulgrave, Victoria, Australia) to confirm the concentration and homogeneity of each element in the tissue standards. BCR185R (bovine liver reference standard) was digested and analysed to measure the digestion recovery. Frozen sections of tissue standards were cut at $30 \mu \mathrm{m}$ on a Leica cryotome (Leica, Solms, Germany) at $-16{ }^{\circ} \mathrm{C}$ and mounted on Starfrost ${ }^{\mathrm{TM}}$ microscope slides (Waldemar Knittel Glasbearbeitungs, Wildhagen, Germany). Sections were air dried prior to use.

The standards of all relevant biometals were prepared at concentrations of biological significance. ${ }^{32}$ Four $4 \mathrm{~mm}$ lines of each standard were ablated to construct the calibration curves (see Table 3). The data was averaged for each calibration level. This analysis was performed in triplicate and the calibration curve was constructed with all three data points for each standard level as an input. The LINEST function in Microsoft Excel was used to determine the standard deviation of the $y$-intercept.

\section{Histological specimens}

All animal experiments conformed to the Australian National Health and Medical Research Council standards of animal care and were carried out in accordance with the requirements of the Howard Florey Animal Ethics Committee. 6 month old male

Table 3 Standard levels and element concentrations $\left(\mu \mathrm{g} \mathrm{g}^{-1}\right.$ )

\begin{tabular}{lccccc}
\hline Level & Mn & Fe & Cu & Zn & Se \\
\hline 1 & 0.0304 & 14.8 & 5.42 & 2.29 & 0.00 \\
2 & 0.528 & 13.7 & 5.49 & 4.17 & 0.0503 \\
3 & 10.0 & 36.6 & 15.9 & 18.1 & 6.77 \\
4 & 1.89 & 47.7 & 24.3 & 27.9 & 0.921 \\
5 & 44.4 & 89.9 & 51.9 & 64.5 & 34.2
\end{tabular}

C57BL/6 mice were raised according to standard animal care protocols and fed normal chow and water ad libitum.

Animals were euthanased with an overdose of sodium pentobarbitone $\left(100 \mathrm{mg} \mathrm{kg} \mathrm{kg}^{-1}\right.$ ) and perfused with $30 \mathrm{~mL}$ of warmed $\left(37^{\circ} \mathrm{C}\right) 0.1 \mathrm{M}$ phosphate buffered saline (PBS), pH 7.4. Tissue was briefly fixed in $4 \%$ paraformaldehyde in PBS until the brains sank (for complete fixation of tissue), after which they were immersed overnight in two changes of $30 \%$ sucrose in PBS (to provide cryoprotection before cryosectioning). ${ }^{33}$ Tissue was then frozen at $-80{ }^{\circ} \mathrm{C}$ and mounted in O.C.T. ${ }^{\mathrm{TM}}$ via the medulla oblongata and upper spinal cord. After equilibrating at $-20{ }^{\circ} \mathrm{C}$, the brains were sectioned using PTFE-coated cryotome blades to $30 \mu \mathrm{m}$ thickness at $90 \mu \mathrm{m}$ intervals and mounted on standard microscope slides.

Collection of human tissue was conducted with ethical approval of the St. Vincent's Hospital Human Ethics Committee and were in accordance with Australian National Health and Medical Research Council Guidelines. Formalin fixed, paraffin embedded sections $(30 \mu \mathrm{m})$ were obtained from a radical prostatectomy sample. Histopathological assessment revealed Gleason grade $3+3$ prostatic adenocarcinoma with focal extracapsular extension, clear margins, and no seminal vesicle involvement.

\section{Results and discussion}

\section{Tune development}

The tunes compared two modes of operation (bandpass and MS/MS) of the ICP-QQQ-MS for the analysis of biologically significant target elements representing those with substantial interferences (Table 1) and with little or no gas contaminant interferences $\left({ }^{63} \mathrm{Cu}\right.$ and $\left.{ }^{66} \mathrm{Zn}\right)$.

Tune 1 (no-gas) served as a reference tune for comparison against tunes 2 and 3 . In typical ICP-SQ-MS, attempts to increase sensitivity by increasing ion transmission results in concomitant increases in interfering polyatomic signals. In contrast, the QQQ configuration removes the confounding signals with increasing ion transmission by exploitation of collisions and reactions in Q2, followed by further mass filtering in Q3. Tune $2\left(\mathrm{H}_{2}\right)$ was performed in bandpass mode which allowed manipulation of ion transmission through Q1 by varying the SLS and SLG parameters. Changing the SLG factor from 0.4 to 0.9 did not result in significant changes of sensitivity and was maintained at 0.9 for all further experiments. Fig. 1 shows a plot of sensitivity and BEC $v s$. SLS factor for copper.

All other target elements had similar profiles. The SLS factor had minimal impact on sensitivity and BEC between 0.5 and 0.7 , and a marked decrease in sensitivity and increase in BEC between 0.7 and 0.8. A SLS factor of 0.7 and a SLG factor of 0.9 gave the maximum sensitivity and minimum BEC and were used for all further experiments. Tune 3 was performed in MS/ MS mode which had fixed values of SLG and SLS to pass specified ions of interest to the reaction cell (Q2) prior to further filtering and detection in Q3. This tune mode was suitable for detecting on-mass or mass-shift ions for kinetically favoured reactions. All elements other than $\mathrm{P}$ and Se were monitored onmass. Although Se has a small positive reaction enthalpy $\left(\mathrm{Se}^{+}+\right.$ 




Fig. 1 Influence of the SLS-factor on the background and the sensitivity of $\mathrm{m} / \mathrm{z} 63, \mathrm{SLG}=0.9$. The same trend was observed for all masses. The lowest background and the highest sensitivity was at a SLS-factor of 0.7. All data was normalised to the calibration curve with the greatest slope.

$\mathrm{O} \rightarrow \mathrm{SeO}^{+} \delta 0.69 \mathrm{eV}$ ), we have previously shown in solution analysis that the $\mathrm{SeO}^{+}$reaction is kinetically favoured. ${ }^{23}$

\section{Sensitivity and limits of analysis}

Table 4 summarises the limits of detection and quantification for all three tunes calculated from calibration curves constructed by laser ablation of each of the tissue standards shown in Table 3.

Small differences in LOD and LOQ were apparent across all of the tunes. The no-gas tune provided similar or better performance for ions free from gas contaminant interferences $\left({ }^{63} \mathrm{Cu}\right.$ and $\left.{ }^{66} \mathrm{Zn}\right)$ when compared against the other tunes. This indicated that mitigation of confounding signals with either reaction or mass shift had a minimal effect on the signal.

Adjusting the bandpass settings in the no-gas and $\mathrm{H}_{2}$ tunes allowed more ions to be transmitted than traditionally occurs with ICP-SQ-MS, leading to increased backgrounds in the nogas tune. However, addition of $\mathrm{H}_{2}$ eliminated these increases and improved the detection limits for ${ }^{55} \mathrm{Mn},{ }^{78} \mathrm{Se},{ }^{80} \mathrm{Se}$ whilst ${ }^{56} \mathrm{Fe}$ remained the same. This is consistent with our previous reports of LOD improvement with $\mathrm{H}_{2}$ tunes with a ICP-SQ-MS. ${ }^{17}$

Table 4 Limits of detection (LODs) and limits of quantification (LOQs) obtained from each of the tunes. LODs and LOQs were calculated from the calibration curves following laser ablation of each of the standards

\begin{tabular}{|c|c|c|c|c|c|c|}
\hline & \multicolumn{3}{|c|}{ LODs $\mu \mathrm{g}^{-1}$} & \multicolumn{3}{|c|}{ LOQs $\mu \mathrm{g} \mathrm{g}^{-1}$} \\
\hline & No-gas & $\mathrm{H}_{2}$ & $\mathrm{O}_{2} / \mathrm{H}_{2}$ & No-gas & $\mathrm{H}_{2}$ & $\mathrm{O}_{2} / \mathrm{H}_{2}$ \\
\hline${ }^{55} \mathrm{Mn}$ & 0.55 & 0.20 & 0.35 & 1.8 & 0.67 & 1.2 \\
\hline${ }^{56} \mathrm{Fe}$ & 2.3 & 2.3 & 2.7 & 7.6 & 7.7 & 9 \\
\hline${ }^{63} \mathrm{Cu}$ & 1.4 & 1.8 & 1.0 & 4.7 & 6.0 & 3.4 \\
\hline${ }^{66} \mathrm{Zn}$ & 1.8 & 3.6 & 2.5 & 6.1 & 11.9 & 8.4 \\
\hline${ }^{78} \mathrm{Se}$ & 0.93 & 0.31 & 1.2 & 3.1 & 1.0 & 4.0 \\
\hline${ }^{80} \mathrm{Se}$ & - & 0.44 & 0.55 & - & 1.5 & 1.8 \\
\hline
\end{tabular}

The mass shift tune resulted in a similar detection limit for ${ }^{80} \mathrm{Se}$ when compared against $\mathrm{H}_{2}$.

\section{EBI of histological samples}

The suitability of the ICP-QQQ-MS for EBI was demonstrated by analysis of two types of histological specimens. The first was biopsy material from a case of prostate cancer, whilst the second was a murine brain which has been well characterised by EBI using ICP-SQ-MS.6,11,34

A prostate cancer tissue biopsy with a Gleason Score of $6(3+$ 3), which represented a mid-range score assigned by the American Society of Clinical Oncology, ${ }^{35}$ in which the cells remain well differentiated, is shown in Fig. 2. This image was obtained with the mass shift tune in order to demonstrate that both on-mass and mass shift analytes may be detected. High levels of $\mathrm{Zn}$ were observed in the tissue and gave clear delineation of the histologically observed margins of the tumour. These findings are consistent with known upregulation of a number of $\mathrm{Zn}$-rich proteins such as $\mathrm{Zn}$-transporter proteins, ZIP9 and $\mathrm{ZEB}^{36,37}$ and suggesting that $\mathrm{Zn}$ or other elemental distributions may be able to provide a useful marker for augmenting current histological grading of prostate cancers. The levels of Se remained at or below the limits of detection even using the $\mathrm{O}_{2} / \mathrm{H}_{2}$ mass shift tune.

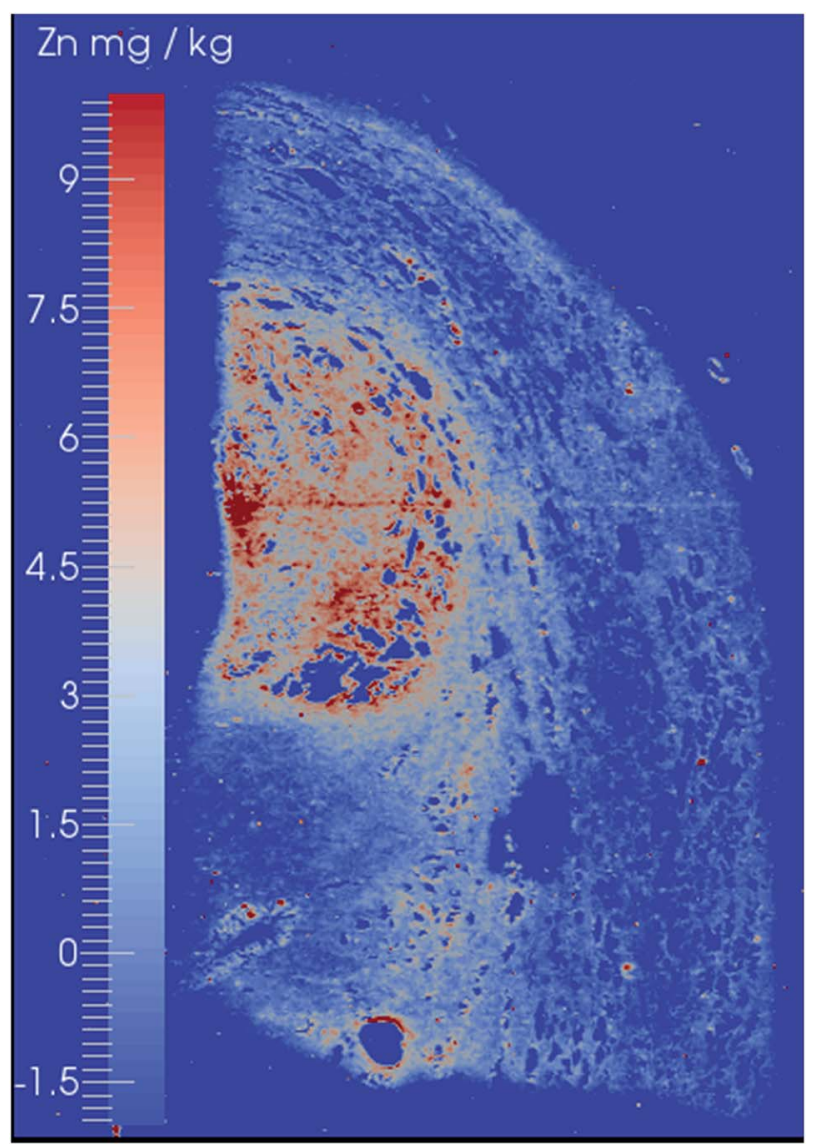

Fig. 2 Zn distribution of a prostate cancer section analysed by LA$I C P-Q Q Q$ and an $\mathrm{O}_{2}$ tune. 




Fig. 3 (a) ${ }^{80} \mathrm{Se} \rightarrow{ }^{80} \mathrm{Se}^{16} \mathrm{O}$ image and (b) ${ }^{31} \mathrm{P} \rightarrow{ }^{31} \mathrm{P}^{16} \mathrm{O}$ image of a mouse brain obtained with LA-ICP-QQQ and an $\mathrm{O}_{2} / \mathrm{H}_{2}$ tune.

Selenium has long been refractory to analysis by EBI. The detection of the two major isotopes, ${ }^{80} \mathrm{Se}$ and ${ }^{78} \mathrm{Se}$, are confounded by polyatomic argon dimers, which are present in a large abundance. The mass shift from $\mathrm{m} / \mathrm{z} 80$ to $\mathrm{m} / \mathrm{z} 96$ effectively moved the Se signal away from the interferences, revealing a Se image of a mouse brain section (Fig. 3(a)). In the majority of applications of LA-ICP-MS, Se quantification is attempted after separation by gel electrophoresis separation, and pre-concentration of the selenoproteins. ${ }^{38-44}$ Se has previously been imaged in mouse models exposed to $\mathrm{Cd}-\mathrm{Se}$ quantum dots with ${ }^{82}$ Se monitored, ${ }^{45}$ and via the O-mass shift on ${ }^{80} \mathrm{Se}$ in sunflower leaves grown in a high Se matrix with a ICP-SQ-MS. ${ }^{46}$ However, mass shift products obtained with an ICP-SQ-MS are still subject to spectral interferences that are not present with ICP-QQQ-MS due to mass filtering in Q1; for example ${ }^{96} \mathrm{Mo}$, ${ }^{96} \mathrm{Ru},{ }^{9} \mathrm{Zr},{ }^{39} \mathrm{~K}^{41} \mathrm{~K}^{16} \mathrm{O}^{+},{ }^{79} \mathrm{Br}^{17} \mathrm{O}^{+}$.

Although dry plasmas used with LA-ICP-MS are not subjected to the same level of polyatomic formation as that of a traditional wet plasma with solution nebulisation, ${ }^{47}$ monoisotopic phosphorus is subject to polyatomic interferences from common gas contaminants such as $\mathrm{N}_{2}$ and $\mathrm{O}_{2}$. The $\mathrm{P} \rightarrow$ PO mass shift is demonstrated in Fig. 3(b). The mass shift effectively removed interferences resulting in backgrounds of approximately 100 cps compared to approximately $2600 \mathrm{cps}$ with LA-ICP-SQ-MS with the $\mathrm{H}_{2}$ tune.

\section{Conclusions}

Three tunes representing the two modes of operation of the ICPQQQ-MS were evaluated for EBI. The no-gas and hydrogen tunes were performed in bandpass mode which allowed increased ion transmission through Q1 via manipulation of the SLS and SLG parameters. The no-gas tune provided excellent sensitivity for those elements less affected by Ar-based spectral interferences. The $\mathrm{H}_{2}$ tune improved the detection limits for elements subject to gas-based interferences whilst maintaining the detection limits of those elements.

The $\mathrm{O}_{2} / \mathrm{H}_{2}$ tune was performed in MS/MS mode and was effective in mass-shifting the signals of $\mathrm{P}$ and Se, whilst maintaining sensitive detection of other elements. A prostate cancer biopsy and mouse brain was run with the $\mathrm{O}_{2}$ tune. A high level of $\mathrm{Zn}$ was identified in the cancerous tissue and phosphorus (P) was readily converted to $\mathrm{PO}$ in the mouse brain. The $\mathrm{S} \rightarrow \mathrm{SeO}$ mass shift was effective for analysis of ${ }^{80} \mathrm{Se}$, the most abundant Se isotope, without the need to account for other spectral interferences on $\mathrm{m} / \mathrm{z} 96$.

\section{Acknowledgements}

The authors' research was supported by Australian Research Council Linkage Project grants (LP100200079, LP120200081), Movember Foundation and the Prostate Cancer Foundation of Australia through a Movember Revolutionary Team Award (EDW) and the Australian Government Department of Health. Associate Professor Kenneth Opeskin (St. Vincent's Hospital Melbourne) kindly provided histopathology expertise.

\section{Notes and references}

1 K. J. Waldron, J. C. Rutherford, D. Ford and N. J. Robinson, Nature, 2009, 460, 823-830.

2 G. N. Landis and J. Tower, Mech. Ageing Dev., 2005, 126, 365379.

3 M. W. Bourassa and L. M. Miller, Metallomics, 2012, 4, 721738.

4 R. McRae, P. Bagchi, S. Sumalekshmy and C. J. Fahrni, Chem. Rev., 2009, 109, 4780-4827.

5 S. G. Brinkhaus, J. Bornhorst, S. Chakraborty, C. A. Wehe, R. Niehaus, O. Reifschneider, M. Aschner and U. Karst, Metallomics, 2014, 6, 617-621.

6 D. J. Hare, P. Lei, S. Ayton, B. R. Roberts, R. Grimm, J. L. George, D. P. Bishop, A. D. Beavis, S. J. Donovan, G. McColl, I. Volitakis, C. L. Masters, P. A. Adlard, R. A. Cherny, A. I. Bush, D. I. Finkelstein and P. A. Doble, Chem. Sci., 2014, 5, 2160-2169.

7 A. Matusch, L. S. Fenn, C. Depboylu, M. Klietz, S. Strohmer, J. A. McLean and J. S. Becker, Anal. Chem., 2012, 84, 31703178.

8 J. S. Becker, M. V. Zoriy, C. Pickhardt, N. Palomero-Gallagher and K. Zilles, Anal. Chem., 2005, 77, 3208-3216.

9 D. Hare, S. Tolmachev, A. James, D. Bishop, C. Austin, F. Fryer and P. Doble, Anal. Chem., 2010, 82, 3176-3182.

10 J. Seuma, J. Bunch, A. Cox, C. McLeod, J. Bell and C. Murray, Proteomics, 2008, 8, 3775-3784.

11 D. Hare, B. Reedy, R. Grimm, S. Wilkins, I. Volitakis, J. L. George, R. A. Cherny, A. I. Bush, D. I. Finkelstein and P. Doble, Metallomics, 2009, 1, 53-58.

12 A. J. Managh, R. W. Hutchinson, P. Riquelme, C. Broichhausen, A. K. Wege, U. Ritter, N. Ahrens, G. E. Koehl, L. Walter, C. Florian, H. J. Schlitt, H. J. Reid, E. K. Geissler, B. L. Sharp and J. A. Hutchinson, J. Immunol., 2014, 193, 2600-2608. 
13 D. Potter, J. Anal. At. Spectrom., 2008, 23, 690-693.

14 D. Pozebon, G. L. Scheffler, V. L. Dressler and M. A. G. Nunes, J. Anal. At. Spectrom., 2014, 29, 2204-2228.

15 S. F. Durrant and N. I. Ward, J. Anal. At. Spectrom., 2005, 20, 821-829.

16 S. D. Tanner, Spectrochim. Acta, Part B, 2002, 57, 1361-1452.

17 J. Lear, D. J. Hare, F. Fryer, P. A. Adlard, D. I. Finkelstein and P. A. Doble, Anal. Chem., 2012, 84, 6707-6714.

18 D. S. Urgast, S. Hill, I.-S. Kwun, J. H. Beattie, H. GoenagaInfante and J. Feldmann, Metallomics, 2012, 4, 1057-1063.

19 D. Pröfrock and A. Prange, Appl. Spectrosc., 2012, 66, 843868.

20 L. Balcaen, G. Woods, M. Resano and F. Vanhaecke, J. Anal. At. Spectrom., 2013, 28, 33-39.

21 R. S. Amais, C. D. B. Amaral, L. L. Fialho, D. Schiavo and J. A. Nobrega, Anal. Methods, 2014, 6, 4516-4520.

22 Y. Anan, Y. Hatakeyama, M. Tokumoto and Y. Ogra, Anal. Sci., 2013, 29, 787-792.

23 D. P. Bishop, D. J. Hare, F. Fryer, R. V. Taudte, B. R. Cardoso, N. Cole and P. A. Doble, Analyst, 2015, 140, 2842-2846.

24 S. D. Fernandez, N. Sugishama, J. R. Encinar and A. SanzMedel, Anal. Chem., 2012, 84, 5851-5857.

25 S. Meyer, M. Matissek, S. M. Mueller, M. S. Taleshi, F. Ebert, K. A. Francesconi and T. Schwerdtle, Metallomics, 2014, 6, 1023-1033.

26 M. Tanimizu, N. Sugiyama, E. Ponzevera and G. Bayon, J. Anal. At. Spectrom., 2013, 28, 1372-1376.

27 K. Boeting, S. Treu, P. Leonhard, C. Heiss and N. H. Bings, J. Anal. At. Spectrom., 2014, 29, 578-582.

28 L. Balcaen, E. Bolea-Fernandez, M. Resano and F. Vanhaecke, Anal. Chim. Acta, 2014, 809, 1-8.

29 J. Zheng, W. Bu, K. Tagami, Y. Shikamori, K. Nakano, S. Uchida and N. Ishii, Anal. Chem., 2014, 86, 7103-7110.

30 T. W. May and R. H. Wiedmeyer, At. Spectrosc., 1998, 19, 150155.

31 D. J. Hare, J. L. George, R. Grimm, S. Wilkins, P. A. Adlard, R. A. Cherny, A. I. Bush, D. I. Finkelstein and P. Doble, Metallomics, 2010, 2, 745-753.
32 D. J. Hare, J. Lear, D. Bishop, A. Beavis and P. A. Doble, Anal. Methods, 2013, 5, 1915-1921.

33 D. J. Hare, J. L. George, L. Bray, I. Volitakis, A. Vais, T. M. Ryan, R. A. Cherny, A. I. Bush, C. L. Masters, P. A. Adlard, P. A. Doble and D. I. Finkelstein, J. Anal. At. Spectrom., 2014, 29, 565-570.

34 D. J. Hare, J. Lear, D. Bishop, A. Beavis and P. A. Doble, Anal. Methods, 2013, 5, 1915-1921.

35 ASCO, Prostate Cancer: Stages, http://www.cancer.net/ cancer-types/prostate-cancer/stages, accessed 11/07/2015, 2015.

36 P. Thomas, Y. F. Pang, J. Dong and A. H. Berg, Endocrinology, 2014, 155, 4250-4265.

37 D. Ren, M. Wang, W. Guo, S. Huang, Z. Y. Wang, X. H. Zhao, H. Du, L. B. Song and X. S. Peng, Cell Tissue Res., 2014, 358, 763-778.

38 G. Ballihaut, L. E. Kilpatrick, E. L. Kilpatrick and W. C. Davis, Metallomics, 2012, 4, 533-538.

39 J. Bianga, G. Ballihaut, C. Pecheyran, Z. Touat, H. Preud'homme, S. Mounicou, L. Chavatte, R. Lobinski and J. Szpunar, J. Anal. At. Spectrom., 2012, 27, 25-32.

40 J. Bianga, E. Govasmark and J. Szpunar, Anal. Chem., 2013, 85, 2037-2043.

41 J. Bianga, Z. Touat-Hamici, K. Bierla, S. Mounicou, J. Szpunar, L. Chatiatte and R. Lobinski, J. Proteomics, 2014, 108, 316-324.

42 M. A. O. da Silva and M. A. Z. Arruda, Microchim. Acta, 2012, 176, 131-136.

43 T. W. M. Fan, E. Pruszkowski and S. Shuttleworth, J. Anal. At. Spectrom., 2002, 17, 1621-1623.

44 Z. Pedrero, S. Murillo, C. Camara, E. Schram, J. B. Luten, I. Feldmann, N. Jakubowski and Y. Madrid, J. Anal. At. Spectrom., 2011, 26, 116-125.

45 T. H. Wang, H. A. Hsieh, Y. K. Hsieh, C. S. Chiang, Y. C. Sun and C. F. Wang, Anal. Bioanal. Chem., 2012, 404, 3025-3036.

46 M. A. O. da Silva and M. A. Z. Arruda, Metallomics, 2013, 5, 62-67.

47 J. S. Becker, H. Sela, J. Dobrowolska, M. Zoriy and J. S. Becker, Int. J. Mass Spectrom., 2008, 270, 1-7. 